\title{
Response of Pearl Millet (Pennicetum Glaucuml.) to Experimental Mutagenesis in the Guinea Savannah Agro-Ecology of Ghana
}

\author{
Isaac K. Addai \\ Department of Agronomy, University for Development Studies, Tamale, Ghana \\ ikaddai2014@gmail.com \\ and
}

Baba Salifu

Faculty of Agriculture and Social Sciences, Anglican

University College of Technology, Ghana

DOI//http://dx.doi.org/10.4314/gjds.v15i1.2

\begin{abstract}
Irradiation techniques were applied to investigate the effect of gamma irradiation on growth and yield of pearl millet (Pennicetum glaucum L.) during the cropping seasons of 2014 to 2016 in Nyankpala, Ghana. Seeds of pearl millet were irradiated with gamma rays at 100, 200 or $300 \mathrm{~Gy}$. The irradiated and some unirradiated control seeds were planted in 2014 in a randomized complete block design with four replications. At harvest, all $M_{1}$ seeds for respective gamma ray doses were harvested and advanced to $M_{2}$ generation during the 2015 cropping season. Mutant lines with desirable agronomic traits from the $M_{2}$ generation were advanced to $M_{3}$ during the 2016 season. Result of screening the $M_{3}$ mutant lines indicated that mutagenesis followed by selection produced desirable agronomic characteristics. Number of productive tillers was the yield component mostly associated with total grain yield. The mutant lines especially those from the 100 and 200 Gy doses of gamma rays recorded significant improvement in earliness, number of productive tillers, seed weight and total grain yield. The early maturing and high yielding mutant lines are being evaluated in multilocational trials for possible release as varieties for northern Ghana.
\end{abstract}

Keywords: Pearl Millet, Growth, Grain Yield, Gamma Irradiation, Induced Mutation 


\section{Introduction}

Millet is widely grown around the world as human food or as feed for livestock. The crop has $97 \%$ its production in the developing countries (McDonough et al., 2000). The most widely grown millet cultivar is pearl millet which is an important crop in India and parts of Africa (Kalaisekar et al., 2017). Millet provides about $75 \%$ of total caloric intake for the poor people living in the semi-arid tropics and sub-humid drought-prone areas. Millets alone provide $13.40 \mathrm{~kg} / \mathrm{yr}$ per capita food use. They are nutritionally equivalent or superior to other cereals. They generally contain high protein (up to $9.5 \mathrm{~g} / 100 \mathrm{~g}$ ), ash, calcium (up to $344 \mathrm{mg} / 100 \mathrm{~g}$ ), phosphorus and potassium (up to $250 \mathrm{mg} / 100 \mathrm{~g}$ and $314 \mathrm{mg} / 100 \mathrm{~g}$ respectively) as well as iron and zinc (Obilana and Manyasa, 2000).

Millet is widely perceived as a crop in terminal decline. It is a neglected and underutilized crop whose yields are low under the local environmental conditions (Salifu, 2015). The crop is distinctive in its adaptability to adverse agro-ecological conditions and requires minimal agronomic inputs with good nutritional properties (Bashir et al., 2011; Subi and Idris, 2013). It is therefore an important crop for household food security, and its resilience to drought can help offset the effects of climate change. Between 1981 and 2012, worldwide production of millets grew by $0.4 \%$ per year and in Africa over the same period, the production of this crop grew by $1.8 \%$ per year (Orr et al, 2016).

Exploitation of natural and induced genetic diversity is the basic requirement for plant breeding in developing plant varieties for sustainable food production (Jain, 2010). More often than not, plant breeders are handicapped due to lack of availability or non-existence of desired genotypes. However, they have successfully recombined certain desired genes from the available gene pool and the related plant species by sexual hybridization. This has successfully helped in developing new cultivars with desirable traits such as high yield, abiotic and biotic stress resistance (Huang et al., 2002).

Induced mutation is one of the best alternatives for improvement of crops as it can help to create and regenerate the variability, which is generally lost in the process of natural selection and adaptation of crops to various stresses (Khan and Goyal, 2009). The frequency of spontaneous mutations is rather very low and difficult to exploit by the plant breeder (Jain, 2010). Thus breeders normally resort to mutagenesis in creating variation during breeding programmes. The purpose of induced mutation is to enhance the mutation frequency in order to select appropriate variants for evaluation and possible release as varieties. Gamma rays have proven to be economical and effective mutagen as compared to other ionizing 
radiations because of its easy availability and relatively high penetration power. The penetration power of gamma irradiation helps in their wide application for the improvement of various plant species (Moussa, 2011). The present study was designed to create genetic variation in pearl millet through mutagenesis and select mutants with improved grain yield and other desirable agronomic traits for release as varieties in northern Ghana.

\section{Materials and Methods}

\section{Description of Study Area}

The studies were conducted at the experimental field of University for Development Studies in Nyankpala, Ghana during the 2014 - 2016 cropping seasons. The experimental sites lie on altitude $183 \mathrm{~m}$, latitude $09^{\circ} 25^{\prime} \mathrm{N}$ and longitude $\mathrm{O}^{\circ} 58^{\prime} \mathrm{W}$. The area has a unimodal rainfall pattern of about $1000 \mathrm{~mm}$ which is evenly distributed from May to October with the peak in August and September. The total annual rainfall is about $1022 \mathrm{~mm}$. The average minimum and maximum temperatures are $25^{\circ} \mathrm{C}$ and $35^{\circ} \mathrm{C}$ respectively (Lawson et al., 2013). The area lies within the interior Guinea savannah of Ghana and is characterized with natural vegetation dominated by grasses with few shrubs. Soils of the area are moderately drained and are free from concretions. The soils are shallow with hardpan under the top few centimetres and were derived from Voltaian sandstone. The soils, according to FAO (1988), are classified as Nyankpala series or Plinthic Acrisol. The area has grassland vegetation and it is interspersed with short trees such as Parkia biglobosa and Azadirachta indica, and weed species such as Centrosema pubescens, Cyperus difformis and Striga hermontheca.

\section{Irradiation and Planting of Seeds}

Seeds of pearl millet (variety Naara) were obtained from Savannah seeds in Tamale, Ghana. The seeds were packed in brown paper envelops and irradiated with 100, 200 and 300 Gy of gamma rays at the Radiation Technology Center (RTC) of Ghana Atomic Energy Commission (GAEC), Accra, Ghana in August 2014. Treated seeds were sown in the field along with some unirradiated control seeds in a randomized complete block design with four replications. All the treatments and the control were planted at a spacing of $25 \mathrm{~cm} \mathrm{x} 75 \mathrm{~cm}$ in plots measuring $5 \mathrm{~m} \mathrm{x} 5 \mathrm{~m}$ in order to raise the $M_{1}$ generation. 


\section{Handling the Mutagen Treated Populations}

All seeds from individual heads per treatment in the $M_{1}$ generation were harvested and replanted for advancement to $\mathrm{M}_{2}$ generation in 2015 in randomized complete block design. In the $\mathrm{M}_{2}$ generation, plants were monitored and screened for superior characteristic using single plant selection procedure and desirable genotypes selected. The superior $M_{2}$ plants were planted to raise the $M_{3}$ generation in 2016 . In $\mathrm{M}_{3}$, the desirable mutant lines were also selected using the same procedure as indicated in the $\mathrm{M}_{2}$ generation.

\section{Weed Control and Scaring of Birds}

In all seasons, weed control was done by hoeing four and seven weeks after planting. Scaring of birds was done to reduce grain loss from seed filling stage up to harvesting.

\section{Data Collection and Statistical Analysis}

Data collected on vegetative and yield parameters at the $M_{1}, M_{2}$ and $M_{3}$ generations included plant height, number of tillers and productive tillers, earliness in flowering, head length, head width, head weight, seed weight and total grain yield. The data were subjected to ANOVA using GENSTAT Statistical package ( $12^{\text {th }}$ edition) and means separated using either Duncan's Multiple Range Test (DMRT) or Least Significant Difference (LSD) at 5\% level of probability.

\section{Results}

\section{Plant Height and Tiller Formation}

Data on plant height is as shown in Table 1. Height of plants was significantly $(\mathrm{P}<0.05)$ affected by gamma irradiation. In the $\mathrm{M}_{1}$ generation, plants from 100 Gy plots recorded the highest height but were significantly similar to the height attained by the control whilst plants irradiated at $300 \mathrm{~Gy}$ of gamma irradiation had the least height. The control plots recorded the least plant height whilst those irradiated at $100 \mathrm{~Gy}$ were the tallest in the $\mathrm{M}_{2}$ generation. In the $\mathrm{M}_{3}$, plants from the three mutant generations recorded significantly similar but higher height than those of the control.

Gamma irradiation had no significant ( $\mathrm{P}>0.05$ ) effect on tillering in the $\mathrm{M}_{1}$ generation (Table 1).Irradiation, however, significantly $(P<0.05)$ influenced this parameter in the $\mathrm{M}_{2}$ and $\mathrm{M}_{3}$ generations. Plants irradiated at $100 \mathrm{~Gy}$ recorded the highest number of tillers whilst the control and $300 \mathrm{~Gy}$ plots recorded the least 
height in the $M_{2}$ generation. In the $M_{3}$, plants from 100, 200 and 300 Gy plots performed significantly similar in terms of number of tillers formed (Table 1 ).

The number of productive tillers were significantly $(\mathrm{P}<0.05)$ affected by the irradiation treatment in all mutant generations. The highest number of productive tillers in the $M_{1}$ generation was recorded by plants from 100 Gy plots but it did not vary from the number recorded by plants from $200 \mathrm{~Gy}$ plots. Similar values of productive tillers were recorded by plants from $300 \mathrm{~Gy}$ and control plots. In the $\mathrm{M}_{2}$ generation, the performance of plants from $100 \mathrm{~Gy}$ plots was at par with plants from the $200 \mathrm{~Gy}$ plots whilst in the $\mathrm{M}_{3}, 100 \mathrm{~Gy}, 200 \mathrm{~Gy}$ and $300 \mathrm{~Gy}$ plots recorded significantly similar but higher number of productive tillers than those from the control.

\section{Earliness in Flowering}

Days to flowering was significantly $(\mathrm{P}<0.05)$ affected by the gamma irradiation treatment. Flowering response to irradiation was similar in $M_{1}$ and $M_{2}$ generations. In $M_{3}$, plants from $100 \mathrm{~Gy}$ plots took the least number of days to attain $50 \%$ flowering and differed significantly from all other treatments, whilst plant from 200 and 300 Gy plots performed significantly similar as shown in Table 1.

\section{Components of Yield and Total Grain Yield}

Gamma irradiation had no significant ( $P>0.05$ ) effect on head length in the $M_{1}$ generation. Gamma irradiation, however significantly $(\mathrm{P}<0.05)$ influenced head length in the $\mathrm{M}_{2}$ and $\mathrm{M}_{3}$ generations. Plants from $100 \mathrm{~Gy}$ plots recorded the highest head length in the $\mathrm{M}_{2}$, followed closely by plants from the 200 or $300 \mathrm{~Gy}$ plots. In the $\mathrm{M}_{3}$ generation, plants from all gamma ray treated plots recorded significantly similar head lengths (Table 2).

The highest head width in the $\mathrm{M}_{1}$ generation was recorded by plants from $100 \mathrm{~Gy}$ plots though these mutants recorded significantly similar values as plants from the unirradiated control plots. In the $\mathrm{M}_{2}$, head width recorded by plants from 100 Gy plots was highest and varied significantly from all other treatments, whilst plants from 200 and 300 Gy plots recorded significantly similar widths. In the $M_{3}$ generation, plants from 100, 200 and 300 Gy recorded significantly similar head widths but differed significantly from the control (Table 2).

No significant ( $P>0.05$ ) variation was observed for head weight in the $M_{1}$ generation, but the parameter varied significantly $(\mathrm{P}<0.05)$ in the $\mathrm{M}_{2}$ and $\mathrm{M}_{3}$ generations. In the $\mathrm{M}_{2}$, plants from the control, $100 \mathrm{~Gy}$, and $200 \mathrm{~Gy}$ plots recorded 
significantly similar head weight. Similar pattern of distribution in head weight as in $\mathrm{M}_{2}$ was also observed in the $\mathrm{M}_{3}$ (Table 2).

Seed weight also varied significantly $(\mathrm{P}<0.05)$ among populations. Plants from the control, 100 Gy and 200 Gy plots recorded significantly similar values of 100 seed weight in the $\mathrm{M}_{1}$ generation. Seed weights recorded by plants from $100 \mathrm{~Gy}$ plots in the $\mathrm{M}_{2}$ generations were similar to those from $200 \mathrm{~Gy}$ and $300 \mathrm{~Gy}$ plots. In the $\mathrm{M}_{3}$ generation, the $200 \mathrm{~Gy}$ and $300 \mathrm{~Gy}$ plots also recorded similar seed weight. Seed weight recorded by 200 Gy plots was significantly higher than those from the 100 Gy and the control plots (Table 2).

Variation in total grain yield is shown in Figure 1. This parameter was significantly $(\mathrm{P}<0.05)$ affected by the irradiation treatment. In the $\mathrm{M}_{1}$ generation, similar grain yield were recorded by plants from $100 \mathrm{~Gy}$ and control plots, as were plants from 200 and $300 \mathrm{~Gy}$ plots. Pattern of total grain yield response to gamma irradiation was similar in the $\mathrm{M}_{2}$ and $\mathrm{M}_{3}$ generations. The overall highest grain yield was recorded by plants from $100 \mathrm{~Gy}$ plots in the $\mathrm{M}_{2}$ and $\mathrm{M}_{3}$ generations.

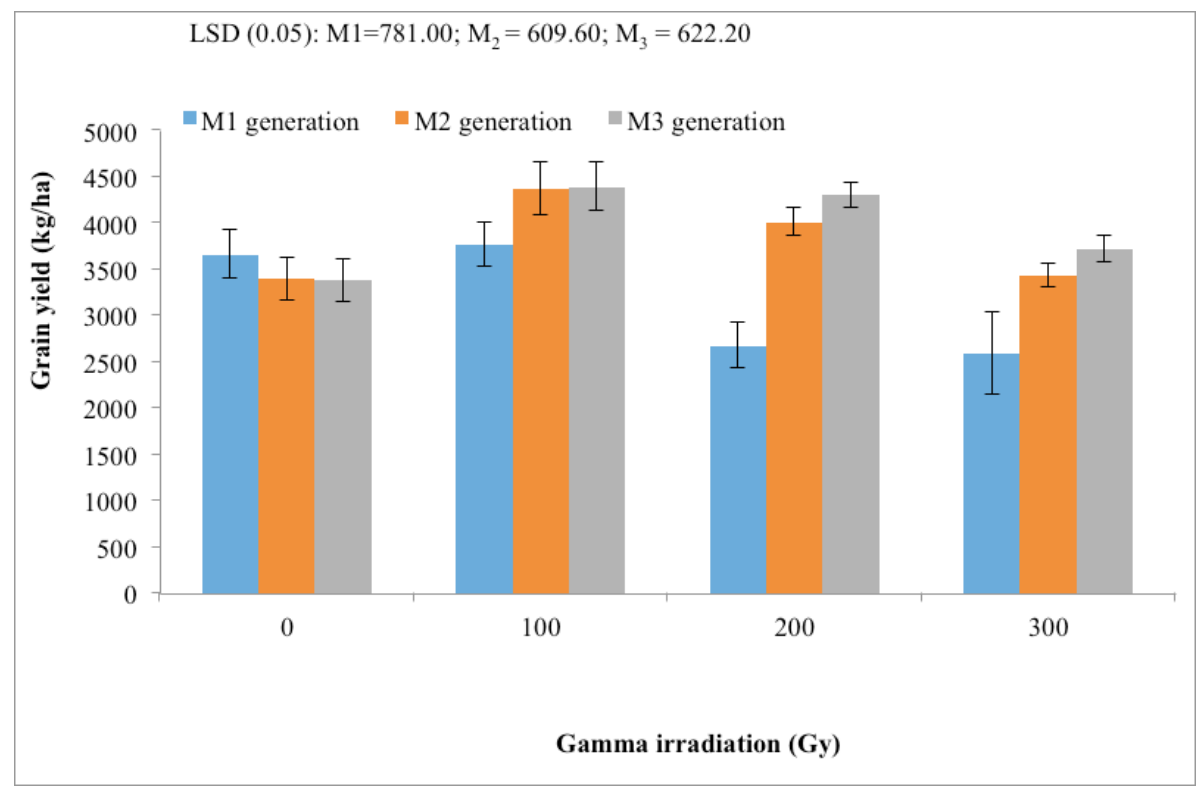

Figure 1: Effect of gamma irradiation on grain yield of millet. Bars indicate mean \pm standard error of the means.

\section{Progress Made in Selection of Agronomic Traits}

Table 3 shows that whilst characters such as plant height and number of productive tillers exhibited high percentage improvements, earliness to maturity and total grain yield recorded lower percentage improvements. Plant height was 
observed to have decreased from $\mathrm{M}_{2}$ to $\mathrm{M}_{3}$ in plants irradiated at the 100 Gy dose, but increased in plants irradiated at 200 and $300 \mathrm{~Gy}$ doses of gamma irradiation. Genetic advancement or gain in selection of important agronomic traits such as plant height, tillering, earliness in maturity period and total grain yield at the $\mathrm{M}_{2}$ and $\mathrm{M}_{3}$ generations was highly variable. For instance, mutants obtained from plants irradiated at 100, 200 and 300 Gy of gamma ray recorded $37.85 \%, 102.81 \%$ and $125.64 \%$ gain in plant height at the $M_{2}$ generation. Similarly, the number of productive tillers also increased by $89.66 \%, 96.43 \%$ and $25.00 \%$ whilst total grain yield increased by $16.10 \%, 50.19 \%$ and $32.21 \%$ at the $M_{2}$ when plants were irradiated at 100, 200 and 300 Gy of gamma rays, respectively. In general, improvements in agronomic traits at the $M_{3}$ generation were higher than those in the $M_{2}$. 
Table 1: Effect of gamma irradiation on plant height, number of tillers, productive tillers and earliness to flowering

\begin{tabular}{|c|c|c|c|c|c|c|c|c|c|c|c|c|}
\hline \multirow[t]{2}{*}{ Irrad. Levels } & \multicolumn{3}{|c|}{ Plant height (cm) } & \multicolumn{3}{|l|}{ Tillers } & \multicolumn{3}{|c|}{ Productive tillers } & \multicolumn{3}{|c|}{ Earliness in flowering (days) } \\
\hline & M1 & $\mathrm{M} 2$ & $\mathrm{M}_{3}$ & M1 & $\mathrm{M} 2$ & $\mathrm{M}_{3}$ & M1 & $\mathrm{M} 2$ & $\mathrm{M}_{3}$ & M1 & $\mathrm{M} 2$ & $\mathrm{M}_{3}$ \\
\hline Control & $71.90 a b$ & $97.70 a$ & $83.90 a$ & 6.03 & $3.66 \mathrm{ad}$ & $3.62 a$ & $1.05 \mathrm{~b}$ & $1.5 \mathrm{ob}$ & $1.38 \mathrm{a}$ & $45 \cdot 75 \mathrm{a}$ & $50.00 a$ & $46.25 a$ \\
\hline $100 \mathrm{~Gy}$ & $90.20 a$ & $124.10 b$ & $118.20 \mathrm{~b}$ & 8.35 & $7.15 \mathrm{~b}$ & $5 \cdot 50 a b$ & $.45 \mathrm{a}$ & $2.75 a$ & $2.97 \mathrm{~b}$ & $41.75 \mathrm{~b}$ & $45.00 \mathrm{~b}$ & $33.00 \mathrm{~b}$ \\
\hline $200 \mathrm{~Gy}$ & $56.90 b c$ & $115 \cdot 40 \mathrm{obc}$ & $126.90 \mathrm{~b}$ & 7.04 & $5.40 \mathrm{C}$ & $6.03 b$ & $1.40 \mathrm{a}$ & $2.75 \mathrm{a}$ & $2.81 \mathrm{~b}$ & $47.50 a$ & $50.00 a$ & $40.25 c$ \\
\hline $300 \mathrm{~Gy}$ & $47.20 c$ & $106.50 \mathrm{C}$ & $119.20 b$ & 6.45 & $4.90 \mathrm{~cd}$ & $6.09 \mathrm{~b}$ & $1.2 \mathrm{ob}$ & $1.5 \mathrm{ob}$ & $2.59 \mathrm{~b}$ & $48.75 a$ & $50.25 a$ & $42.75 \mathrm{ac}$ \\
\hline LSD (0.05) & 22.40 & 9.86 & 23.17 & $5.00 \mathrm{NS}$ & 1.39 & 2.27 & 0.18 & 1.08 & 1.03 & 3.52 & 3.90 & 4.35 \\
\hline
\end{tabular}

Irrad. = irradiation; NS = Not significant; Means followed by the same letter (s) in each column are not significantly different

Table 2: Effect of gamma irradiation on head length, width, weight and 100 seeds weight

\begin{tabular}{|c|c|c|c|c|c|c|c|c|c|c|c|c|}
\hline \multirow[t]{2}{*}{ Irrad. Levels } & \multicolumn{3}{|c|}{ Head Length $(\mathrm{cm})$} & \multicolumn{3}{|c|}{ Head Width (cm) } & \multicolumn{3}{|c|}{ Head Weight (g) } & \multicolumn{3}{|c|}{ 10o Seed Weight (g) } \\
\hline & $\mathrm{M}_{1}$ & $\mathrm{M} 2$ & $\mathrm{M}_{3}$ & M1 & $\mathrm{M} 2$ & $\mathrm{M}_{3}$ & M1 & $\mathrm{M} 2$ & $\mathrm{M}_{3}$ & $\mathrm{M}_{1}$ & M2 & $\mathrm{M}_{3}$ \\
\hline Control & 16.15 & $13.10 \mathrm{C}$ & $12.18 \mathrm{a}$ & $2.72 \mathrm{ac}$ & $2.36 a$ & $2.14 a$ & 12.29 & $25.1 \mathrm{a}$ & $20.86 a b$ & $1.41 \mathrm{a}$ & $0.85 b$ & $0.74 a$ \\
\hline $100 \mathrm{~Gy}$ & 16.64 & $16.74 a$ & $17.45 \mathrm{~b}$ & $2.78 a$ & $2.67 \mathrm{~b}$ & $2.84 \mathrm{~b}$ & 16.16 & $22.4 \mathrm{oab}$ & $22.81 \mathrm{ab}$ & $1.29 \mathrm{ab}$ & $1.07 a$ & $1.56 \mathrm{ac}$ \\
\hline $200 \mathrm{~Gy}$ & 16.23 & $15 \cdot 32 b$ & $15.43 \mathrm{ab}$ & $2.57 \mathrm{bc}$ & $2.52 \mathrm{C}$ & $2.74 \mathrm{~b}$ & 12.62 & $20.50 a b$ & $23.55 a$ & $1.29 \mathrm{ab}$ & $1.01 \mathrm{a}$ & $1.96 \mathrm{~b}$ \\
\hline $300 \mathrm{~Gy}$ & 15.74 & $14.30 b c$ & $16.6 \mathrm{ob}$ & $2.45 \mathrm{~b}$ & $2.48 c$ & $2.71 b$ & 15.09 & $16.3 \mathrm{~b}$ & $20.83 b$ & $1.24 \mathrm{~b}$ & $0.95 a b$ & $1.66 \mathrm{bc}$ \\
\hline LSD (0.05) & $1.02 \mathrm{NS}$ & 1.21 & 3.84 & 0.17 & 0.13 & 0.34 & 6.ooNS & 6.46 & 2.94 & 0.16 & 0.13 & 0.85 \\
\hline
\end{tabular}

Irrad. = irradiation; NS= Not significant; Means followed by the same letter (s) in each column are not significantly different 
Table 3: Improvements made in some agronomic traits of Pearl millet through mutagenesis using gamma irradiation

\begin{tabular}{|c|c|c|c|c|c|c|c|c|c|c|}
\hline Irrad. levels & Character & $\mathbf{M}_{1}$ & $\mathrm{M}_{2}$ & $\mathrm{M}_{3}$ & $\mathrm{M}_{2}-\mathrm{M}_{1}$ & $\mathbf{M}_{3}-\mathbf{M}_{1}$ & $M_{3}-M_{2}$ & $\begin{array}{l}{\left[\left(\mathrm{M}_{2}-\mathrm{M}_{1}\right) /\right.} \\
\left.\mathrm{M}_{1}\right] 100\end{array}$ & $\begin{array}{l}{\left[\left(M_{3}-M_{1}\right) /\right.} \\
\left.M_{1}\right] 100\end{array}$ & $\begin{array}{l}{\left[\left(M_{3}-M_{2}\right) /\right.} \\
\left.M_{2}\right] 100\end{array}$ \\
\hline \multirow[t]{4}{*}{$100 \mathrm{~Gy}$} & Plant height & 90.20 & 124.1 & 118.2 & 33.90 & 28 & -4.75 & 37.85 & 31.04 & -4.75 \\
\hline & Productive tillers & 1.40 & 2.75 & 2.97 & 1.30 & 1.52 & 0.22 & 89.66 & 104.83 & 8.00 \\
\hline & Earliness & 41.70 & 45.00 & 33.00 & 3.25 & -8.75 & -12.00 & 8.89 & -0.21 & 26.67 \\
\hline & Grain yield & 3758.00 & 4363.00 & 4381.0 & 605.00 & 623.00 & 18.00 & 16.10 & 16.58 & 0.41 \\
\hline \multirow[t]{4}{*}{$200 \mathrm{~Gy}$} & Plant height & 56.90 & 115.40 & 126.90 & 58.50 & 70.00 & 11.50 & 102.81 & 123.02 & 9.97 \\
\hline & Productive tiller & 1.40 & 2.75 & 2.81 & 1.35 & 1.41 & 0.06 & 96.43 & 100.71 & 2.18 \\
\hline & Earliness & 47.50 & 50.00 & 40.25 & 2.50 & -7.25 & -9.75 & 5.26 & -15.26 & 19 \\
\hline & Grain yield & 2668.00 & 4007.00 & 4296.0 & 1339.0 & 1628.0 & 289.00 & 50.19 & 61.02 & 7.21 \\
\hline \multirow[t]{4}{*}{$300 \mathrm{~Gy}$} & Plant height & 47.20 & 106.5 & 119.20 & $59 \cdot 30$ & 72.00 & 12.7 & 125.64 & 152.54 & 11.92 \\
\hline & Productive tiller & 1.20 & 1.50 & 2.59 & 0.30 & 1.39 & 1.09 & 25.00 & 115.83 & 72.67 \\
\hline & Earliness & 48.75 & 50.25 & 42.75 & 1.50 & -6.00 & $-7 \cdot 50$ & 3.08 & 12.31 & 14.93 \\
\hline & Grain yield & 2589.0 & 3423.0 & 3717.0 & 834.00 & 1128.0 & 294.00 & 32.21 & 43.68 & 8.59 \\
\hline
\end{tabular}




\section{Discussion}

Data obtained from the present studies revealed that mutagenesis using gamma irradiation created genetic variation that served as basis for selecting mutants with desirable agronomic traits in millet. Y1ldız and Ceylan (2015) also demonstrated that mutagenesis using gamma rays could increase the nutritional value of barley. Values of genetic advancement or gain in selection as recorded in the present study are in conformity with the results obtained for sesame and groundnut by Mathur et al. (2000).There was a stimulatory effect on plant height in this study, and this was observed especially with the lower doses of gamma irradiation. This agrees with the finding by Wi et al. (2007) that low doses of gamma irradiation may induce growth stimulation in plants. These authors explained that stimulation of plant growth by low doses of gamma rays occur through changes in the hormonal signaling network or by increasing the anti-oxidative capacity of the cells to overcome stress factors such as fluctuations in light intensity and temperature during the period of plant growth and development. According to Zaka et al. (2004), the stimulatory effect on plant growth is attributed to changes in the rates of cell division as well as activation of growth hormones such as auxin in the treated populations. In the present study, the high irradiation dose (300 Gy) resulted in growth inhibition particularly at the $M_{1}$ generation. The inhibition of growth according to Preussa and Britta (2003) might have been caused by the cell cycle arrest at the G2/M phase during somatic cell division and/or various damages in the entire genome of the plants following irradiation.

In plant production, the formation and development of buds occur at an early stage of growth. Available evidence (Koli et al., 2002) indicates that an increase in kinetin/auxin ratio may increase the formation of buds, leaves and shoots. Kinetin is known to increase the proliferation of tillers. Gamma irradiation might have influenced the biochemical processes that are known to regulate the rate and pattern of apical differentiation and this could have had a direct effect on production and proliferation of tillers. The low gamma ray doses might have played a pivotal role in maintaining this hormonal balance in the irradiated plants. Reduction in tillering at higher doses as observed in this study might have resulted from reduced mitotic activities in the meristematic tissues of pearl millet which resulted from low moisture content in the seeds of the irradiated plants prior to planting (Muhammad and Afsari, 2001). Reduction in number of tillers of crops planted after irradiation at high gamma ray doses has also been reported by AlSalhi et al. (2004), Token et al. (2005) and Kon et al. (2007). Norfadzrin et al. (2007) also noticed that high gamma ray doses had negative effect on morphological characteristics of tomato and okra. 
The study has demonstrated that irradiation using gamma rays can change the number of days to flowering in plants. Karim et al. (2008) also reported that gamma irradiation has the potential to change flowering dates of plants. Mutagenesis using gamma irradiation may create variability in flowering dates of plants and this will assist breeders in selecting early or late flowering plants for crop improvement. In this study, the low dose of gamma irradiation (100 Gy) was capable of stimulating early flowering in millet especially at the $\mathrm{M}_{2}$ and $\mathrm{M}_{3}$ generations whilst the high doses were not. Jan et al. (2012) explained that biological damage resulting from seedling injury, lethality and sterility in crops may occur with increases in doses of gamma irradiation during mutagenesis and that the suppressive effect on flowering by high doses of gamma rays may have been related to the combined effects of auxin and DNA biogenesis in a relationship. Decreases in root and shoot growth by high doses of gamma rays have also been observed in finger millet (Ambavane et al., 2015).

The beneficial effect of gamma rays on grain yield has been reported by Kon et al. (2007) who observed an increase in yield at low doses of gamma irradiation and a decrease at higher doses in long bean. Maman et al. (2010) observed that yield differences in agronomic crops are associated with variations in yield components. In the present study, the low doses of gamma rays ( $100 \mathrm{~Gy}$ and $200 \mathrm{~Gy}$ ) enhanced the formation of productive tillers, head weight, and 100 seed weight more than the high dose (300 Gy) and the control and this reflected in the relatively high grain yield of the former as compared with the latter. The observation made in this study is in agreement with the findings of Majeed et al. (2010) who reported that reduction in grain yield at higher doses of irradiation was as a result of reduced plant stature or reduced moisture contents in shoot due to radiation effect. The data presented in the present work indicated that plants that were high yielding were also tall and those that were short due to their exposure to high irradiation dose were low yielding.

\section{Conclusion}

Mutagenesis using gamma irradiation created genetic variability in pearl millet that served as basis of selection of mutants with improved agronomic traits. Among the gamma ray treatments, $100 \mathrm{~Gy}$ and $200 \mathrm{~Gy}$ predominantly enhanced growth and yield parameters in all the generations as compared to the unirradiated control. Though, 200 and 300 Gy gamma ray treatments performed less than the control in some of the parameters measured in the $\mathrm{M}_{1}$ generation, the performances of plants irradiated at $200 \mathrm{~Gy}$ or $300 \mathrm{~Gy}$ were significantly better than the unirradiated control in the $M_{2}$ and $M_{3}$ 
generations. Gamma - induced mutagenesis enhanced earliness in flowering. Mutants derived from all gamma treatments plants flowered earlier than the unirradiated control especially in the $\mathrm{M}_{3}$ generations, among which $100 \mathrm{~Gy}$ was outstanding. The high yielding and early flowering mutant lines especially those from 100 Gy or 200 Gy doses when released as varieties will play a major role in breaking the yield constraints in pearl millet and improve the economic status of farmers in the study area.

\section{Acknowledgement}

The authors of this study are most grateful to the Faculty of Agriculture of UDS for providing funds for land preparation prior to planting. Sincere thanks also go to all technicians of the Department of Agronomy, UDS for their help in data collection, weeding and other cultural practices.

\section{References}

Al-Salhi, M., Ghannam, M. M., Al-Ayed, M. S., El - Kameesy, S. U. and Roshdy, S. (2004). Effect of gamma irradiation on the biophysical and morphological properties of corn. Nahrung, Vol. 48, pp. $95-98$.

Ambavane, A.R., S.V. Sawantdesai, S.A., Gokhale, N.B. (2015). Studies on mutagenic effectiveness and efficiency of gamma rays and its effect on quantitative traits in finger millet (Eleusine coracana L. Gaertn). Journal of Radiation Research and Applied Sciences, Vol. 8, No. 1, pp. 120-125.

Bashir E., Haussmann B., Ali A., Ismail M., Abdalla E., Bakhit O., Sabeel S., Muth P. and Parzies H. (2011). Genetic analysis and biofortification of pearl millet for nutritional values. Conference of Development on the margin, Tropentag 2011, October 5-7, Bonn, Germany.

FAO (1988). Soil Map of the World, Revised Legend, Reprinted with corrections. World Soil Resources Report 60, FAO, Rome.

Huang, J., Rozell, S., Pray, C. and Wang, Q. (2002). Plant biotechnology in China. Science, Vol. 295, pp. 674-677.

Jain, S. M. (2010). Mutagenesis in crop improvement under the climate change. Romanian Biotechnological Letters, Vol. 15, No. 2, pp. 88-106.

Kalaisekar, A., Padmaja, P.G., Bhagwat, V.R. and Patil, J. V. (2017). Systematics, Bionomics, and Management. In: Insect Pests of Millets, ISBN: 978-0-12804243-4, Academic press, pp. 1-25. 
Jan, S., Parween T., Siddiqi, T.O. and Uzzafar, M. (2012). Effect of gamma radiation on morphological, biochemical and physiological aspects of plants and plant products. Environment Review, Vol. 20, pp. 17-39.

Karim, K.M.R., Islam, A.K.M.R., Hossain, M.M., Azad, H.M.S. and Rahman, W.M. (2008). Effect of gamma rays on yield attributes of large seeded chickpea. Journal of Soil Nature, Vol. 2, No. 2, pp. 19-24.

Khan, S. and Goyal, S. (2009). Mutation genetics studies in mungbean IV: Selection of early maturing mutants. Thai Journal of Agricultural Science, Vol. 42, No. 2, pp.109-113.

Koli, N.R., Sharma, Y. and Sharma, Y. (2002). Gamma rays induced variation in cumin (Cuminum cyminum, L.). Annalsof Agriculture and Biology Research, Vol. 7, No. 2, pp. 161-164.

Kon, E., Ahmed, O.H., Saamin, S. and Majid, N.M. (2007). Gamma radiosensitivity study in Long Bean (Vigna sesquipedalis). American Journal of Applied Science, Vol. 4, No. 12, pp. 1090-1093.

Lawson, I.Y.D., Issahaku, A., Acheampong, S.K., Adams, B. and Tuffour, V. (2013). Time of planting and weed suppression abilities of some legumes intercropped with maize in the Guinea savanna zone of Ghana. Agriculture and Biology Journal of North America, Vol. 4, pp. 358-363.

Majeed, A., Rehman, K.A.U., Habib, A. and Zahir, M. (2010). Gamma irradiation effect on some growth parameters of Lepidium sativum L. ARPN. Journal of Agriculture and Biological Science, Vol. 5, No. 1, pp. 39-42.

Maman, N., Mason, S., Lyon, D.J. and Dhungana, P. (2010). Yield components of pearl millet and grain sorghum across environments in the Central Great Plains. Panhandle Research and Extension Center. Paper III.

Mathur, R.K., Manivel, P., Samder, M.Y., Gor, H.K. and Chikani, B.M. (200o). Creation of genetic variability through mutation breeding in groundnut. Proceedings of the DAE-BRNS symposium on the use of nuclear and molecular techniques in crop improvement. December 6-8, 2000. Bhabha Atomic Research Centre, Mumbai, India. pp. 203-213.

Muhammad, R. and Afsari, S. (2001). Quantitative variations induced by gamma irradiation and gibberellic acid in $\mathrm{M}_{1}$ generation of chick pea. Sarhad Journal of Agriculture, Vol. 17, No. 3, pp. 367-372.

Moussa, H.R. (2011). Low dose of gamma irradiation enhanced drought tolerance in soybean.Acta Agronomica Hungarica, Vol. 59, pp. 1-12. 
McDonough, C.M., Rooney, L.W. and Serna-Sadivar, S.o. (2000). The millets. Food science and Technology: Handbook of cereal science and technology, CRC Press, $2^{\text {nd }}$ edition, pp. 117-210.

Norfadzrin, F., Ahmed, O.H., Shaharudin, S. and Rahman, D.A. (2007). A preliminary study on gamma radio-sensitivity of tomato (Lycopersicon esculentum) and okra (Abelmoschus esculentus). International Journal of Agricultural Research, Vol.2, No. 7, pp. 620-625.

Obilana, A.B. and Manyasa, E. (2002). Millets. In Pseudocereals and less common cereals: grain properties and utilization potential, P.S. Belton and J.R.N. Taylor (eds), Springer-Verlag, Berlin Heidelberg New York, pp. 177-217.

Orr, A., Mwema, C., Gierend, A. and Nedumaran, S. (2016). Sorghum and Millets in Eastern and Southern Africa. Facts, Trends and Outlook. Working Paper Series No. 62. ICRISAT ResearchProgramme, Markets, Institutions and Policies. Patancheru 502 324, Telangana, India: International Crops Research Institute for the Semi-Arid Tropics. $76 \mathrm{pp}$.

Preussa, S.B. and Britta, A.B. (2003). A DNA-damage - induced cell cycle checkpoint in Arabidopsis. Genetics, Vol. 164, pp. 323-334.

Salifu, B. (2015). Effects of Cobalt - 60 gamma irradiation on growth and yield of pearl millet (Pennisetum Glaucum L.) in the Guinea Savannah Agroecological Zone of Ghana. Master of Philosophy Thesis, Department of Agronomy, Faculty of Agriculture, University For Development Studies, Ghana, pp. 99.

Subi, M.I.M. and Idris, A.E. (2013). Genetic variability, heritability and genetic advance in pearl millet (Penisetum glaucum [L.] R. Br.) genotypes. British Biotechnology Journal, Vol. 3, No. 1, pp. 54-65.

Token, C.B., Uzun, H. and Canci, C.F.O. (2005). Effects of gamma irradiation on the shoot length of cicer seeds. Radiation Physics and Chemistry, Vol. 73, No. 6, pp. 365-367.

van Oosterom, E.J., O'Leary, G.J., Carberry, P.S. and Craufurd, P.Q. (2002). Simulating growth, development, and yield of tillering pearl. Field Crops Research, Vol. 79, pp. 85-106.

Wi, S.G., Chung, B.Y., Kim, J.H., Baek, M.H., Yang, D.H., Lee, J.W. and Kim, J.S. (2007). Effects of gamma irradiation on morphological changes and biological responses in plants. Micron, Vol. 38, pp. 553-564.

Y1ld1z, T. and Ceylan, N.(2015). The Effects of using gamma irradiated wheat and barley in layer diets on egg production and quality. Turkish Journal of Agriculture - Food Science and Technology,Vol. 3, No. 9, pp.742-747. 
Zaka, R., Chenal, C. and Misset, M.T. (2004). Effect of low doses of short-term gamma radiation on growth and development through two generations of Pisum sativum. Science of the Total Environment, Vol. 320, pp. 121-129. 